\title{
DIGITAL TOOLS IN ACQUISITION OF THEMES ABOUT ETHNICALLY VARIED CULTURE ENVIRONMENT OF LATGALE
}

\author{
Olga Senkāne \\ RHEI REGI \\ Karīne Laganovska \\ RHEI REGI
}

\begin{abstract}
The object of the particular research is involvement of students in informative stockbuilding of a regional museum during research practice. The aim of the research is to carry out evaluation of this form of involvement and its advantages: using discourse analysis (Jean Liotard); putting forward particular indicators; as well as applying several communication theories (Nikolai Nikishin, Yuri Lotman, Peter van Mensch); and regarding virtual museum as a special communication system based on non-verbal communication of visitors with exhibits. Possible benefits of the museum in this evaluation are of minor importance. The most significant aspect is to reveal student's (museum employee's during the research practice) as 'sender's' role in cognition and non-verbal communication with the addressee or the museum visitor. It is demonstrated in coordinated and still independent work, frequently oriented towards self-initiative, creative solutions based on particular knowledge and simultaneously initiating acquisition of new information, as well as promoting development of skills. These skills include communicating with an interviewee; carrying out content analysis of media text, identifying features of stereotypical thinking; creating brief but still informatively capacious description of an exhibit.

The use of digital tools during the study process is completely related to scientific activities of academic staff in the implementation of research projects oriented towards innovations as well as provision of stable feedback. If the research is carried out in tight relationship of scientists and students; everyone wins: students help academic staff (thus create conditions for their own research), carry out creative work, make own discoveries, because materials necessary for research are already collected and accordingly supplied; while academic staff develops students' professional competences by coordinating practical work, following their theoretical knowledge, skills and abilities, promoting creative solutions and thus educate new generation of scientists tempered in performing preparatory actions and open for innovations, elaboration and implementation of own creative research projects.
\end{abstract}

Keywords: Jewish cultural heritage, virtual museum, text corpus, study process.

\section{Introduction}

In ethnically diverse Latgale Jewish minority has appeared in the spotlight of social and cultural processes because of rapid decrease in the number of bearers of this peculiar culture as well as because of losing own ethnic identity in many ways by assimilating. Cities and towns of Latgale mainly store historical and cultural evidence in the form of out-of-museum objects: burial places, preaching houses, synagogues, schools, buildings and their remains, as well as monuments and memorial hatchments, some other historical signs. For example, in Kraslava there are many authentic Jewish-built and earlier inhabited wooden, stone 
buildings, "matza" cellar, leather factories, public bath-house, a.o. buildings. It seems that time hasn't influenced former Jewish blocks of the provincial town much. Jewish culture has left deep footsteps in Latgalian folklore and literature. Unfortunately regional museums do not have special expositions revealing local Jewish history because of the lack of exhibits. If the number of items to display is insufficient to make a separate thematic exposition in at least one regional museum, the museums can cooperate for elaboration of one joint virtual exposition. The leading researchers of the Scientific Institute for Regional Studies (REGI) of Rezekne Higher Education Institution were so overwhelmed with this idea that got involved in a project "Holokaust in Latgale Remembrance Strategies for Universities and Teachers (2010-2012) financed by Friedrich Ebert Foundation (FES) and oriented towards a cultural dialog and culture tourism development. The main activity within the project is development of electronic tools for maintenance and popularization of region's Jewish cultural heritage, but the most significant product is - a regional virtual museum "Jews in Latgale" (www.regionalistika.lv), including video filmstestimonies, educational seminars, courses for teachers and museum workers (professional in-service training program for teachers "Cultural Heritage and History of Jews in Latgale").

In the field research lasting for three years close relationship was made with museums in Latgale: Latgale Museum of Culture History, Ludza Local History Museum, Malta Museum of History, Varakḷāni County Museum, Viļāni Local History Museum, Krāslava History and Art Museum, Preili Museum of History and Applied Art. They participate not only in supplementing the virtual museum with photos, documents, descriptions of exhibits, but in perspective will create a joint tourism route in Latgale emphasizing pre-Holocaust Jewish culture testimonies.

During the expeditions video interviews with Latgale long-livers (Henrihs Čužāns [Henrich Chuzhans] (born in 1924), Viktors Airapetovs, Roha Moisejeva [Rokha Moiseyeva] (born in 1926) and others) were made. A video interview allows all viewers to feel the effect of presence - to walk through the surroundings, to listen to a live narration of real eye-witnesses without any rehearsals. Currently the museum exposition consists of:

1) audio-interviews with abstracts (in the future there could also be video interviews);

2) photo materials of out-of-museum culture objects with descriptions;

3) photo materials of museum exhibits with descriptions;

4) documents and other testimonies (memoirs);

5) video films about particular Jews' inhabited regions in historical and contemporary perspective; 
6) sociological surveys of students and pupils ascertaining that modern youth has insufficient competence in very significant ethnos in culture history so characteristic for Latgale peculiarity.

The database of the virtual museum "Jews in Latgale" consists of a material testimonies collection to be found in the collections of different museums of Latgale, new gains acquired in field researches by REGI scientists. For example, there are handwritten memoirs "Nazi Terror in Viḷāni" by Vladislavs Zeps, as well as already mentioned photos of out-of-museum objects - buildings, cemeteries, monuments, memorial planks, and other signs of the past in the landscape of provincial towns. The main advantage of a virtual museum is its unlimited accessibility as well as mutually non-verbal communication of the addressee (visitor) and the sender (museum employer). Besides, it provides convenient and fast ways to stock up, improve or close expositions, include new or change, for example, interactive tools (surveys, questions). A sender cannot be anonymous, his vision, social and culture position can be felt in the choice of exhibits, design and description, while the addressee can state his or her position about the contents in the interactive part of the museum. There are no problems concerning preservation of museum objects, etc.

The exhibits of a virtual museum exposition have the features of museum objects and in some cases they even have advantages over classic museums. Exhibits of a virtual museum are:

1) available any time any place as well as interpreting socially significant information;

2) sustained without time limits in terms of storage;

3) immediately communicating;

4) open for attractiveness, catching visitors' attention;

5) expressive, effective (are able to create associations, emotions);

6) representative (create a notion about things in general);

7) aesthetic;

8) entertaining, involving interactive tools (Никишин 1998).

But most importantly, they are able to carry out an educational function, foster scientific research, and cause emotional experience without direct participation of a museum employee or verbal communication. Although non-verbal articulation of culture codes is a museum exposition creator's competence, a museum exhibit communicates with a visitor and basically is a mediator between the exposition's compiler and observer.

\section{Materials and Methods of Research}

Currently virtual exhibition is modern; museums apply it in practice in order to attract visitors more effectively. The mission of the virtual museum "Jews in Latgale" is to include, arrange separate fragmentary material culture testimonies 
of Jews in Latgale in a shared integrating virtual room available for an unlimited number of people who are interested in it. The vision of the museum is to create a real virtual museum with multi-medial exhibitions, reference tools, virtual card files, thematic expositions and a system of virtual excursions basing on collected materials. Such an intention is quite an impossible task for three or four researchers, therefore the idea to involve students, particularly those of Rezekne Higher Education Institution taking studies in the academic bachelor study program "History". In addition, research practice in a virtual museum could be for students from other programs of the humanities or engineering science within a module of regional studies. Particular the bachelor study program "History" offers "Museology and museum practice" (48 hours), a study course "Jews in Latvia/Latgale: Holocaust" (32 hours) within the module "History periodization and research", as well as study paper themes for researching culture history of Jews in Latgale. Previously students of the corresponding study program participated in expeditions of REGI scientists as interviewers, and it was the only collaboration of scientists with students.

The object of the particular research is involvement of students in informative stock-building in the regional museum during research practice. The aim of the research is to carry out evaluation of this form of involvement and advantages using discourse analysis (Jean Liotard), putting forward particular quality indicators (Лиотар 1998), as well as several communication theories (Nikolai Nikishin, Yuri Lotman, Peter van Mensch) regarding the virtual museum as a special communication system based on non-verbal communication of a visitor with exhibits (Mensch 1992). Possible benefits of the museum in this evaluation are not that important. The most significant aspect is to reveal student's (museum employee's during the research practice) as 'sender's' role in cognition and non-verbal communication with the addressee or the museum visitor. It is demonstrated in coordinated and still independent work, frequently oriented towards self-initiative, creative solutions based on particular knowledge and simultaneously initiating acquisition of new information, as well as promoting development of skills. These skills include communicating with an interviewee; carrying out content analysis of media text, identifying features of stereotypical thinking; creating brief but still informatively capacious description of an exhibit.

In the regional, ethnically diverse identity the culture-social discourse of Latgale Jewish minority plays a fragmentary local role. It is related mainly to the subject of holocaust and several pre-holocaust economic, educational, social and cultural processes' indicators, which formally are included into a set of multicultural environment indications without deeper comprehension of regularities and other generalizations. It is also proved by autonomous and sporadic actions in finding and demonstrating Jewish culture signs within the framework of wider thematic expositions and exhibitions in local museums. 
Anticipated activity and interaction of creators of the virtual museum "Jews in Latgale" and that of visitors, i.e., senders and addressees, are oriented towards a socio-cultural dialog mainly in the national memory discourse. It includes deepened exploration, research and popularization of culture values of the corresponding ethnos allowing to realize its actual meaning and place in the regional identity creation from the historical and, which is important, modern comprehensive point of view.

Participation of students in informative collection building of the virtual museum can provide the main communication quality indicator of museum operation - a feedback in the context of theoretical knowledge, research, scientific research and its popularization as well as application of their results. Independent research activity as individual absorption in the corresponding dialog themes of various cultures initiates development of stable coherence in student's awareness between knowledge and understanding, facts and events, experience and memory, episode and panorama.

During student's research practice or development of a study paper about a corresponding theme a virtual museum offers opportunities to get introduced with authentic Jewish culture signs in the landscape of populated places in the region and anthropogenic environment. It is achieved by implementing activities related mainly to documenting, compiling and selection, in other words museum's informative stocking up:

1) in real museums, archives, libraries, study of available materials on the Internet in relation to the creation of description about an exhibit, formulation of interactive part of the virtual museum (questions and offered answers);

2) preparation of gathered materials for publication on the museum's website (scanning, descriptions of exhibits, their editing);

3) field researches (exploration and photographing, as well as recording audio and video interviews of signs and testimonies);

4) processing of video and audio materials (description and transcription);

5) carrying out of sociological surveys as well as summarizing their results;

6) participation in scientific conferences and seminars with presentation of the results of field researches, sociological surveys, analysis of archive materials, etc., as well as preparation of presentation materials for publication in the museum.

The above mentioned activities anticipate topical procedures for museology collecting, storage and translation, as well as processes specific for the chronotope - communication and socialization. The communicative information translation system is as important result as collection of museum objects. Basically the main task of a student is provision of translation - searching for museum exhibits and full informative stock-building anticipating not just acquisition of new systems and technologies, but also innovation, thus actually 
widening communicative and educational opportunities of the museum. Students can also carry out selection of the acquired material if the criteria are clearly formulated. A very significant factor of museum work is the personal attitude of a sender towards the exhibit as an item of particular exposition and a theme of the museum or exposition in general. Searching for museum objects, as well as their selection and processing can be formal, oriented towards observing only the conditions mentioned in practice guidelines, revealing sufficient/insufficient knowledge, skills and abilities. The content and system of the virtual museum "Jews in Latgale" promote a sender (as well as an addressee) to axiological excursus in one's own cognition (see the slide show on the front page of the museum website), emotional food for thought about the socio-cultural essence of own contribution and nature of mission not only in the regional or national context. Here not only the formula of knowledge, but also comprehension starts to operate. It contains not just memories, but also memory cultures, not just episodes, fragments, synechdoches, but also a panoramic view of the whole, which is an invaluable component of formation of an educated and intellectual person's world perception. A trainee's task is to achieve a choice of exhibits and their design by converting culture and history code content that rouse corresponding intentional (sender's intended) associative or emotional addressee's interpretation. Possibilities of multimedia a.o. e-tools in structuring and paradigmatics of the chronotope in the virtual museum (e.g. exhibits in 3D, thematic all-round slide shows revealing particular exhibits, photo collages, video clips with interactive tasks, etc.) in these terms are unlimited.

The most significant indicator of student's practical skills and competences is synthesis of theoretical knowledge and practical skills in one's created or at least projected thematic exposition, activity, publication (article, guidebook, catalog, video guide, etc.), development of supplementary aids (maps, schemes, diagrams, a.o.). There might be even offered an interesting, untraditional, methodological solution for communication of the virtual museum with the addressees suitable for a particular age group: attractive participation in the night of museums or popularization of the museum in social networks by organizing clubs, competitions, quizzes, games, consultations, etc.

All students' designed and implemented a museum communication act oriented towards feedback (opposite to formal practice). It shall be valued as a result of productive practice - a peak of mutual interaction of theoretical and practical knowledge, as well as skills and abilities (see Table 1 "Indicators of museum research practice productivity"). 
Indicators of museum research practice productivity Muzeju pētnieciskās prakses produktivitātes indikatori

\begin{tabular}{|c|c|c|}
\hline Culture-social discourse & Communicative discourse & $\begin{array}{c}\text { Professional competences } \\
\text { discourse }\end{array}$ \\
\hline $\begin{array}{l}\text { 1. Perception of the } \\
\text { museum as an institution } \\
\text { cultivating culture } \\
\text { memory: respect of } \\
\text { addressee's axiological } \\
\text { reactions in provision of } \\
\text { translation of museum } \\
\text { information (content and } \\
\text { aesthetics of design of } \\
\text { expositions and exhibits). } \\
\text { 2. Selection of associative, } \\
\text { emotionally and } \\
\text { correspondingly notable } \\
\text { materials for exposition, } \\
\text { orienting oneself in } \\
\text { culture semiotics } \\
\text { (symbols, stereotypes, } \\
\text { subtexts of details). } \\
\text { 3. Respect of an ethnically } \\
\text { diverse, multicultural } \\
\text { identity concept in } \\
\text { research (purposefulness } \\
\text { of field researches, study } \\
\text { of archives and other } \\
\text { materials) and } \\
\text { interpretation of research } \\
\text { results. }\end{array}$ & $\begin{array}{l}\text { 1. Comprehension of a museum } \\
\text { as a special communicative } \\
\text { system; awareness of virtual } \\
\text { museum's advantages and } \\
\text { peculiarities: provision of } \\
\text { effectiveness of the information } \\
\text { (exposition) translation process } \\
\text { (informative interactive } \\
\text { presentation of stock-building } \\
\text { results). } \\
\text { 2. Well considered photo, video } \\
\text { and audio materials selection } \\
\text { conformable with thematics } \\
\text { and intentions, as well as } \\
\text { interesting and educational } \\
\text { exhibits descriptions for } \\
\text { addressees. } \\
\text { 3. Development and } \\
\text { popularization of educational } \\
\text { and instructional interactive } \\
\text { museum tools in social } \\
\text { networks. } \\
\text { 4. Productive work in field } \\
\text { researches (quality and } \\
\text { statistics of interviews) and } \\
\text { sociological surveys. }\end{array}$ & $\begin{array}{l}\text { 1. Knowledge and skills } \\
\text { (existing and acquired) for } \\
\text { informative stocking up of } \\
\text { the museum to translate } \\
\text { information, as well as its } \\
\text { usage in searching for } \\
\text { exhibits, their selection, } \\
\text { description, processing, } \\
\text { layout a.o. } \\
\text { 2. Creative solutions for } \\
\text { traditional museum } \\
\text { employee's activities and } \\
\text { products (new systems, } \\
\text { technologies, forms, a.o., } \\
\text { to attract and educate new } \\
\text { visitors). } \\
\text { 3. Active research activity } \\
\text { (gathering of information, } \\
\text { collecting, systematizing, } \\
\text { analyzing, research } \\
\text { material; using it for } \\
\text { educating museum } \\
\text { visitors), publication of } \\
\text { articles, participation in } \\
\text { conferences and seminars } \\
\text { with presentations. }\end{array}$ \\
\hline
\end{tabular}

The results of students' research practice can be unlimitedly available and objectively evaluable, because the virtual museum provides an option to record the attendance statistics of expositions and even individual exhibits as well as references and assessments. Therefore feedback as the basic criterion of museum informative stock efficiency can be easily identified. Besides, it must be considered that a project developed and implemented by a student is interdisciplinary (information technologies, design, psycho-sociolignuistics, etc.). A special role in selection and compiling of exposition material is devoted to culture semiotics. Awareness of symbol subtexts, interpretations of culture signs potential as well as stereotypes dominant in society optimizes the work of virtual translation. A trainee must respect differences in perception of the same exhibit because of various experiences and memories. Therefore material selection and design (both visual and textual) is a very responsible process requiring not only good intuition, but also specific knowledge. A trainee-sender must take into account the percepts of society about cultural heritage of Latgale 
Jews regarding the peculiarity of this ethnic minority and its expressions in the format of culture signs (wooden and stone architecture, cemeteries, cult buildings and objects, food, etc.) in order to:

1) 1widen a possibly narrow point of view of museum visitors;

2) infringe deeply rooted and wrong stereotypes;

3) rouse evaluation of the historical role and place of the ethnos in the context of present-day culture peculiarity within the region.

The heuristic research aspect is very significant in students' education and it can be provoked not only by interpreting innovative museum material and other projects, but also in field researches, archives and scientific analysis of textual material acquired by other means. There is a necessity to carry out a study on texts available nowadays, providing their availability for individual research due to two reasons. Firstly, the Jewish culture remembrance discourse is characterized by the historical evaluation of holocaust and pre-holocaust periods, neglecting contemporary regional, ethnically varied identity indications. Secondly, the opportunities to get valuable, objective material for research are very limited (because of illnesses and deaths of long-livers possibilities to get testimonies of eyewitnesses rapidly decrease; participation of Jews in regional culture and social processes is mainly reflected in the local media, especially in the press). Therefore the opportunities offered by Moodle environment for provision of students' interdisciplinary scientific researches in the whole study process could be very convenient besides the opportunities to develop professional skills (in informative stocking up of the virtual museum) during research practice.

The publications in the regional press ("Ludzas Zeme", "Rēzeknes Vēstis", "Vaduguns", "Novadnieks", "Darba Karogs", "Vietējā Latgales Avīze", "Панорама Резекне") are significant evidence of contemporary Jewish cultural heritage perception and interpretation. Therefore REGI researchers have studied and summarized this textual material creating digitalized text corpus, which, though partly at the moment, is available for definite people. Individual colorful corpus items were published on REGI website for the needs of the in-service training program for teachers "Cultural Heritage and History of Jews in Latgale" (http://ekursi.ru.lv/) implemented by REGI, clarifying and demonstrating introspective interpretation of media text, processing of facts, analysis of text synchretism and functions.

Cognitive evaluation of press texts allows reconstructing region's multicultural landscape from the early 1930s to the late 1940s: destinies of people, events, actions (savers' topic). They reveal the sender's objective and subjective perception of time and space, attitude and axiology, and contain particular sociocultural experience represented in contextual usage of corresponding keywords ("Jew", "year", "Latvia", "holocaust"). Therefore, they are assessed as informatively varied and wide interdisciplinary research materials (history, 
culture history, sociolinguistics, semiotics, etc.) which can be integrated into theoretical history and culture studies. It is typical for press texts to have variable structure, basic components of which (headline, sub-headline, introduction, main textual part - the message (chronological/retrospective/justified, etc.), conclusion or summary) are mutually semantically related. Taking into account specific features of press texts' structure and functions, it is advisable to carry out their research according to the definite plan resultant from text structure, ascertaining structural items or segment functions and informative load.

Introspective analysis of a text can be started by the headline, because it is a very important source of information and a provider of information as well as a maintainer of communication. Its general function is to address the reader and to raise interest about the contents of the text. Therefore headlines are graphically highlited, they are emotionally expressive and contain local references, for instance, "Holocaust was severe in Preilil", "Jews in Malta parish", "Ludzanians stand up in memory of holocaust victims".

The milestone of the press text is an introduction, which along with the headline, opens the topic/issue. The body consists of a discussion specifying and expanding the issue. Conclusion summarizes the main cognitions or tells about sender's conclusions. The conclusion can foster a sender to formulate one's own opinion or act.

The press texts are a rich source of facts. Most frequently time references (year, date, day) can be observed, for example, in the headline - "It happened in summer of 1941" (Rēzeknes Vēstis July 3, 2004). Different numbers and statistical data are topical in the press texts: age of a life story subject in a particular period, number of Nazi victims, etc. Carrying out the analysis of facts included in the press texts, one has to keep in mind that:

- numbers bear particular information;

- precision of facts means a high degree of credibility in description of an event;

- chronological references specify the events of the past at present, mark definite time boundaries;

- numbers are not just statistics, they also have an emotional end expressive function.

In the article "Tragic fate of Jewish people" by a teacher of Baltinava secondary school Imants Slišāns states: "Numbers are just statistics, but they hide the tragedy of Jewish people - genocide." (Vaduguns, July 5, 1997).

Media texts mostly reproduce socio-cultural stereotypes of the age that can be discovered by the method of semiotics. Text analysis anticipates semantic structures of symbols used within the text, the context of symbol usage as well as subtexts' relations research in mutual communication perspective between a sender and an addressee; they are particularly topical in the aspect of 
student's/pupil's heuristic searches. In such text analysis the researchers must respect various interpretations as well as consider their communicative functions:

1) enlightening of an addressee;

2) maintenance of collective culture remembrance (choice of symbols);

3) proposal for an addressee to self-actualize (usage of traditional, stereotypical or new means of expression as well as facts to raise food for thought);

4) inclusion in culture context (in any discourse) (Лотман 1992).

Innovative (digitalized text corpus of the regional press) methodology for using media articles in a study or research paper is a step towards education consistent with contemporary requirements. In the age of information technology it is a great opportunity to bond the content of studies with scientific research of students, development of their proficiency. A practical teaching aid for usage in comprehensive school syllabuses is created by involving students in stocking up corresponding text corpus (digitalization, processing with concordance programs, preparation of tasks, etc.). The electronic format allows activating, supplementing and perfecting the corresponding text corpus and forms of its analysis for an unlimited number of times. Just as in the traditional learning process the study aid in e-environment must be qualitatively prepared and well structured to ensure independent and systematic learning. Using the opportunities offered by digital resources "Blended learning" is developed in pedagogical practice, when e-learning is integrated into the traditional form of learning, but information technologies supplement and enrich traditional acquisition of the subject. E-learning as a form of learning complying with the requirements of the modern society challenges education institutions to develop and offer innovative study and lifelong learning courses filling them with topical contents.

\section{Conclusions}

In general it must be admitted that the use of digital tools during the study process would definitely be related to scientific activities of academic staff in implementation of research projects oriented towards innovations as well as provision of stable feedback. If the research is carried out in tight relationship of scientists and students, everyone wins. On the one hand, students help academic staff (simultaneously create conditions for their own research work), carry out creative work, make own discoveries because materials necessary for research are already collected and accordingly supplied. On the other hand, academic staff develops students' professional competences by coordinating practical work, following their theoretical knowledge, skills and abilities, promoting creative solutions and thus educate a new generation of scientists tempered in 
performing preparatory actions and open for innovations, elaboration and implementation of new independent research projects.

\section{Kopsavilkums}

Konkrētā pētījuma objekts ir studējošo iesaiste reǵionālā muzeja informatīvā komplektēšanā pētnieciskās prakses laikā, bet mērķis ir veikt š̄is iesaistes veidu un priekšrocību izvērtējumu ar diskursa analīzi (Žans Liotārs), izvirzot noteiktus indikatorus, kā arī ar vairāku komunikācijas teoriju (Nikolajs Nikišins, Jurijs Lotmans, Peters Menšs) pielietojumu, uzlūkojot virtuālo muzeju kā īpašu komunikāciju sistēmu. Digitālo rīku izmantojums studiju procesā visnotal saistāms ar akadēmiskā personāla zinātnisko aktivitāti dažādu uz inovācijām orientētu pētniecisku projektu īstenošanā un stabilas atgriezeniskās saites nodrošināšanā. Ja pētījums tiek veikts ciešā zinātnieku un studējošo sadarbībā, ieguvēji ir abas puses: studējošais palīdz akadēmiskajam personālam nodoties jaunradei, veikt atklājumus nenovirzoties, jo pētniecībai nepieciešamais materiāls ir savākts un atbilstoši nokomplektēts. Savukārt akadēmiskais personāls, koordinējot studējošā praktisko darbību, sekojot viṇa teorētisko zināšanu, prasmju un iemaņu samēram, rosinot uz kreatīviem risinājumiem, attīsta studenta profesionālās kompetences un tādējādi izaudzina jauno zinātnieku paaudzi, kas norūdīta pētniecības „priekšdarbu” veikšanā un ir atvērta inovācijām, savu pētniecisko projektu izstrādei un īstenošanai.

\section{Bibliography}

1. Mensch Peter. (1992). Communication. The language of exhibitions. (Version viewed: http://www.muuseum.ee/uploads/files/mensch22.htm (19.02.2013.))

2. Лиотар Жан Франсуа. (1998). Состояние постмодернизма. (Version viewed: http://www.gumer.info/bogoslov_Buks/Philos/liot/index.php (20.02.2013.)

3. Лотман Юрий. (1992). Семиотика культуры и понятие текста. Избранные статьи. (Version viewed: http://www.philology.ru/literature1/lotman-92b.htm (20.02.2013.)

4. Никишин Николай и др. (1998). Музей и коммуникаџия. Конщепџия развития Самарского областного историко-краеведческого музея им. П.В. Алабина. (Version viewed: http://www.future.museum.ru/lmp/projects/samara/site/concept/contents.htm (19.02.2013.)

5. Newspapers: Vietējā Avīze, Rēzeknes Vēstis, Ludzas Zeme, Панорама Резекне, Novadnieks, Vaduguns, Darba karogs, Diena, Latvijas Vèstnesis (Period1991-2012).

\begin{tabular}{|r|l|}
\hline Olga & Rezekne Higher Education Institutions, REGI \\
Senkāne & Rezekne, Atbrivosanas aleja115, Rezekne, \\
& Latvia, Lv-4601 \\
& e-pasts: nikola7@inbox.lv \\
\hline Karīne & Rezekne Higher Education Institutions, REGI \\
Laganovska & $\begin{array}{l}\text { Rezekne, Atbrivosanas aleja115, Rezekne, } \\
\text { Latvia, Lv-4601 } \\
\text { e-pasts: Karine.Laganovska@ru.lv }\end{array}$ \\
\hline
\end{tabular}

